\title{
Optimizing ceftolozane-tazobactam dosage during continuous renal replacement therapy: additional insights
}

\author{
Patrick M. Honore*, Aude Mugisha, Leonel Barreto Gutierrez, Sebastien Redant, Keitiane Kaefer, \\ Andrea Gallerani and David De Bels
}

We read the recent report by Aguilar et al., who concluded that among patients with nosocomial peritonitis who are on continuous renal replacement therapy (CRRT), ceftolozane-tazobactam $(\mathrm{C} / \mathrm{T})$ at a dose of $3 \mathrm{~g}$ every $8 \mathrm{~h}$ is safe [1]. This finding was additional information following the notion that CRRT was an independent predictor of clinical failure when $\mathrm{C} / \mathrm{T}$ was administered at $1.5 \mathrm{~g}$ every $8 \mathrm{~h}$ [2]. The Aguilar et al. protocol included a short infusion time, i.e., $1 \mathrm{~h}$ [1]. Previously described extended-infusion over $4 \mathrm{~h}$ was found to reach above the minimal inhibitory concentration (MIC), given that beta-lactam antibiotics exhibit time-dependent antibacterial activity [3]. This might prevent underdosing during CRRT [3]. Besides, the $\mathrm{C} / \mathrm{T}$ elimination was explained by diffusion [1]. However, adsorption was not assessed. The acrylonitrile 69 Multiflow (AN-69-M) membrane, used in this study, has a lower adsorptive capacity compared with the AN69 surface-treated (AN69-ST) membrane, which is considered a highly adsorptive membrane (HAM). In a recent comparison of polysulphone versus $\mathrm{AN}-69-\mathrm{M}$ for $\mathrm{C} / \mathrm{T}$ extraction by CRRT in an ex vivo model [4], there was no difference in adsorption. In a case report, a continuous infusion (CI) of $6 \mathrm{~g}$ in $24 \mathrm{~h}$ of $\mathrm{C} / \mathrm{T}$ was used in a cystic fibrosis patient with a multidrug-resistant (MDR) Pseudomonas aeruginosa and augmented renal clearance to optimize time-dependent antibacterial activity [5]. In this patient, therapeutic drug monitoring (TDM) confirmed adequate exposure [5]. CI and TDM are two critical parameters when using $\mathrm{C} / \mathrm{T}$ for patients receiving CRRT especially when MICs of bacteria like MDR P. aeruginosa are considered very high.

\footnotetext{
* Correspondence: Patrick.Honore@CHU-Brugmann.be

This comment refers to the article available at https://doi.org/10.1186/ s13054-019-2434-5.

ICU Department, Centre Hospitalier Universitaire Brugmann, Place Van Gehuchtenplein 4, 1020 Brussels, Belgium
}

\begin{abstract}
Abbreviations
AN-69-M: Acrylonitrile 69 Multiflow; AN-69-ST: AN69-surface treated; C/ T: Ceftolozane-tazobactam; Cl: Continuous infusion; CRRT: Continuous renal replacement therapy; HAM: Highly adsorptive membranes; MDR: Multi-drug resistant; MIC: Minimal inhibitory concentration
\end{abstract}

\begin{abstract}
Acknowledgements
We would like to thank Prof. Kianoush Kashani, MD, PhD, FCCP (Mayo Clinic, Rochester, USA) for critically reviewing the manuscript.
\end{abstract}

\begin{abstract}
Authors' contributions
$\mathrm{PMH}$ and DDB designed the paper. All authors participated in the drafting and reviewing. All authors read and approved the final version of the manuscript.
\end{abstract}

Funding

None.

Availability of data and materials Not applicable.

Ethics approval and consent to participate Not applicable.

\section{Consent for publication}

Not applicable.

\begin{abstract}
Competing interests
The authors declare that they have no competing interests.
\end{abstract}

Received: 5 October 2019 Accepted: 29 November 2019

Published online: 12 December 2019

\section{References}

1. Aquilar G, Ferriols R, Martínez-Castro S, Ezquer C, Pastor E, Carbonell JA, Alós $M$, Navarro D. Optimizing ceftolozane-tazobactam dosage in critically ill patients during continuous venovenous hemodiafiltration. Crit Care. 2019; 23(1):145. https://doi.org/10.1186/s13054-019-2434-5.

2. Mussini C, Righi E, Tascini C, et al. Ceftolozane/tazobactam for the treatment of serious $P$. aeruginosa infections: a multicenter nationwide clinical experience. Int J Antimicrob Agents. 2018;53(4):408-15. https://doi.org/10. 1016/j.jjantimicag.2018.11.001 Epub 2018 Nov 8.

3. Oliver WD, Heil EL, Gonzales JP, Mehrotra S, Robinett K, Saleeb P, Nicolau DP. Ceftolozane-tazobactam pharmacokinetics in a critically ill patient on continuous venovenous hemofiltration. Antimicrob Agents Chemother. 2015;60(3):1899-901. https://doi.org/10.1128/AAC.02608-15.

4. Chaijamorn W, Shaw AR, Lewis SJ, Mueller BA. Ex vivo ceftolozane/tazobactam clearance during continuous renal replacement therapy. Blood Purif. 2017; 44(1):16-23. https://doi.org/10.1159/000455897 Epub 2017 Feb 25.

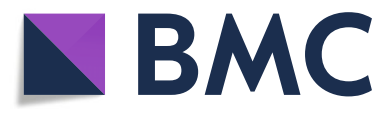

(c) The Author(s). 2019 Open Access This article is distributed under the terms of the Creative Commons Attribution 4.0 International License (http://creativecommons.org/licenses/by/4.0/), which permits unrestricted use, distribution, and reproduction in any medium, provided you give appropriate credit to the original author(s) and the source, provide a link to the Creative Commons license, and indicate if changes were made. The Creative Commons Public Domain Dedication waiver (http://creativecommons.org/publicdomain/zero/1.0/) applies to the data made available in this article, unless otherwise stated. 
5. Elizabeth Davis S, Ham J, Hucks J, Gould A, Foster R, Ann Justo J, Nicolau DP, Bookstaver PB. Use of continuous infusion ceftolozane-tazobactam with therapeutic drug monitoring in a patient with cystic fibrosis. Am J Health Syst Pharm. 2019;76(8):501-4. https://doi.org/10.1093/ajhp/zxz011.

\section{Publisher's Note}

Springer Nature remains neutral with regard to jurisdictional claims in published maps and institutional affiliations. 